\title{
7 The Transfiguration of Samburu Religion
}

Presented with two wholly incompatible accounts of Samburu religion, any reader is entitled to ask how these renderings might coexist or how the earlier version might have been historically transformed into its successor. This chapter examines the evidence as a step towards resolving this issue, taking seriously the possibility of a historical change in belief that has accompanied the transition of the Samburu from a protected colonial enclave to their exposure to a changing world in the course of one generation.

The earlier account was first presented as a conference paper entitled 'The Dynamics of Samburu Religion'. This was elaborated in my book The Samburu (1965). That volume and its sequel, Nomads in Alliance (1973), focused especially on the role of ceremonial behaviour in maintaining a traditionally structured society that showed little evidence of change in $1960 .^{1}$

The more recent account is Bilinda Straight's Miracles and Extraordinary Experience in Northern Kenya (2007). Straight focuses on Samburu religious beliefs rather than ceremony as such. The account is based on extended periods of fieldwork, and it contains some original and detailed insights into Samburu perceptions of the family, contagion, and their responses to death in 2002. The two accounts were therefore effectively 42 years apart, or just three age-sets in Samburu terms - that is one male generation: those of Kimaniki age-set who were moran at the time of my fieldwork were 'fathers of moran' during Straight's time. Whatever the explanation of the more extraordinary aspects of Samburu religious experience that are reported by Straight, they need to be examined for their relevance in the Samburu scheme of things. ${ }^{2}$

\subsection{Misfortune and the Curse}

\subsubsection{Explanations of Misfortune among the Samburu in $\mathbf{1 9 6 0}$}

In 1960, the Samburu suggested that misfortune could be the result of a curse or of unpropitious forces that were only dimly understood. Each of these related in different ways to two dominant institutions that characterised Samburu society: the age system and clanship.

1 My principal fieldwork among the Samburu was conducted in 1957-60 with a revisit in 1962, and my account in this chapter reflects their society as it was in 1960.

2 Straight's fieldwork was conducted in 1992-4 and 2001-2 with three briefer revisits in 2003-5. Of the 33 interviews that she records, 26 occurred in 2001-2, and only 3 before then. I therefore assume that her account reflects Samburu society as it was in 2002. (Straight 2007: ix, 22, 29). 
In their age system, moran were grouped into an age-set that spanned about 14 years before the next age-set was formed to replace them. In the imposed peace of colonial rule, the moran were in a limbo between boyhood and elderhood. They were not allowed to marry and were effectively adolescents even into their late twenties, with their own notions of honour and prestige. A major source of tension was between moran and married elders, notably over stock-theft and adultery. Ultimate control over the moran lay with their firestick patrons who were two age-sets above them, that is elders in their forties and fifties. Social order hinged on the respect - amounting to fear - that the moran had for the powerful curse that these patrons held over them. Elders of more senior age-sets were to be respected because most of them were fathers of moran, and their age was held to give them a more general power to curse. ${ }^{3}$

The second institution was the division of Samburu society into 'sections' or patrilineal clans. The Masula section inaugurated each new age-set every 14 years or so, but beyond this, elders of each section or clan were autonomous in arranging their own ceremonial cycle of activities associated with the age-set system. Clansmen normally lived together in loose clusters of settlements, and kept close company. They might migrate to join their clansmen in another cluster, or occasionally settle temporally with another clan cluster, but essentially as outsiders. Loyalty within the clan was paramount, and this was fanned by the tensions between different clans. Among moran, inter-clan rivalries could build up to confrontations and even feuding, but this was held in check as far as possible by the firestick patrons on both sides acting in concert. ${ }^{4}$

Between elders of different clans, there was the irresolvable issue of unlimited marriage payments that could never be finally settled. While these debts were between families, the fact of clan exogamy meant that they were also between clans, fuelling their mutual mistrust and impinging on the status of women as sisters and daughters on one side and as wives and mothers on the other. The wife-givers could claim a powerful curse over the children of their 'sisters' and 'daughters' if their expectations for further marriage payments were disregarded by the wife-receivers, that is by the husbands of these women in the first generation and then by their sons in the next. Not all mother's-brothers were viewed as predators in this way, but as a general category, they were mistrusted as insatiable scroungers. ${ }^{5}$

The premise of the curse of firestick patrons within the age system and of wifegiving mother's-brothers within the clan system reflected the major lines of cleavages in Samburu society. The more general notion of cursing as an ability of older men characterised the Samburu as a gerontocracy. However, a spirit of moderation prevailed, extending to the society as a whole. All clans wanted to be seen as worthy,

3 Spencer 1965: 81-3, 107-11, 140, 148, 153; 1973: 149.

4 Spencer 1965: 20-2, 74, 113-17, 1973: 86.

5 Spencer 1965: 35-8. 
and mistrust between them was mitigated by a concern for reputation. To be known as predatory wife-givers - constantly demanding further marriage payments with the lurking possibility of a curse - would deter other clans from seeking wives from this clan. It was therefore in the interest of the clan to be moderate in their demands and to restrain their more greedy members. Similarly, elders with grudges against younger men were expected to be reluctant to resort to their power to curse, except in extreme cases. A preferred alternative was to wait until their adversary proposed to marry a girl whom they could curse as a 'daughter' of their clan or age-set. The marriage would then be postponed until the adversary had settled the grievance with gifts, and goodwill was then restored without direct resort to the curse. It was even permissible for a man with a serious grievance to oppose the marriage of an older man of the adjacent senior age-set. However to attempt this against an elder who was older still would risk his curse for gross disrespect. The restraint that Samburu claimed in avoiding resort to their curse was highlighted by their criticism of their Rendille allies to their east. The Rendille regarded the indirect threat of a curse as a sign of weakness, and were reputed to have a more powerful curse and to use it more readily. ${ }^{6}$

If a Samburu suffered unexplained misfortune, then this might suggest a hidden curse arising from some earlier episode of his life. If he could track this down, then it was possible to settle the grievance with the offer of gifts. The worst outcome would occur if the cursor had died and no restitution was possible. Misfortune would dog him and his descendants for the rest of their lives. ${ }^{7}$

An alternative source of misfortune was held to be an unpropitious object or action, such as mishandling some ritual detail. Thus misfortune that seemed to dog a particular age-set or family or individual might be the result of some ritual oversight rather than a curse. Individuals might seek the help of a local diviner (oloiboni) to diagnose the problem and to resolve it with suitable ritual and 'medicines'. However, it was the clan elders (and not a diviner) who were more generally responsible for overseeing ritual affairs within the community. ${ }^{8}$

The Samburu recognised the possibility of sorcery as a cause of misfortune, where some malefactor might deliberately perform an unpropitious act directed at his victim. However, there was no general concern over this, and it was associated more with peripheral communities of hunter/gatherers (Dorobo), who did not share the same patterns of respect as Samburu. Another cause of personal misfortune could be the penetrating 'eyes' of certain people, such as their north-western Turkana neighbours, who felt jealous when they saw someone eating food. ${ }^{9}$ These beliefs followed a consistent pattern - neighbours of the Samburu were to be mistrusted for

\footnotetext{
6 Spencer 1965: 35, 193-206, 297-8

7 Spencer 1965: 187

8 Spencer 1965: 185; 1973: 114-5.

9 Spencer 1965: 185-6; 1973:117, 119
} 
their mystical powers: Rendille for not restraining their more powerful curse; Dorobo for resorting to sorcery; and Turkana for causing harm through the greed in their 'eyes'. Each of these was held to contrast with the moderate restraint displayed by the Samburu among themselves. The moral thrust of their social system maintained control over the high-spirited moran and set limits to the rivalry between clans. Their resort to the curse was seen as justified only as a final resort in an ultimate appeal to mystical forces.

\subsubsection{The Anatomy of Fortune and Misfortune among the Samburu in 2002}

Bilinda Straight's more recent explanation of misfortune among the Samburu does not directly challenge the earlier model, but she expands it in some interesting ways that undermine the basic notion of gerontocracy. In her account, as in 1960, a curse is only uttered in anger as a final resort, and its effect may be immediate and terrible or the threat of misfortune may linger over the generations. However, the effectiveness of a curse is not held to stem just from the anger of older people but from anyone who has been wronged, especially through selfishness as occurs when a hungry person is refused food. ${ }^{10}$

In Straight's analysis, a process is involved whereby the eyes of the offended person are said to witness the wrong and to alert the stomach. Anger builds up in the stomach and is transformed into a curse. This then erupts from the stomach to the heart, and then to the breath and saliva, culminating in the voice that utters the curse. This may be accompanied by inauspicious gestures that signal the strength of feeling. The anger then springs into the body of the wrongdoer where it invades every particle of his (or her) being, inflicting disaster. At other times, an unvoiced curse may emanate directly through a less explicit 'form of anger from people or animals [that have been] cheated, murdered, or killed by another'. ${ }^{11}$

The only remedy following a curse is for the curser to pronounce a blessing. This too has its origin in the stomach, dispelling the festering anger and restoring normal relations. The blessing involves an invocation, with gentle spitting and a gesture with the herding stick. There is no other certain way of annulling a curse, and if the curser dies before pronouncing a blessing, the victim faces the prospect of unlimited misfortune, which is passed down to descendants over the next nine age-sets. ${ }^{12}$

'Anyone' with a just cause can curse another person. Certain families who have migrated from Rendille are thought to have a powerful gift for cursing and blessing, but 'almost every family' has an affinity with some kind of natural object or species of

10 Straight 2007: 96-9.

11 Straight 2007: 96-9, 109, 158-9.

12 Straight 2007: 96-9, 103-4, 109. 
animal that they can use in order to harm or help others. Particular types of relationship are associated with the ability to curse. The firestick patrons have a powerful curse over the moran [as previously noted], but the 'most potent' curse passes between close relatives who share food. 'Many incidents of misfortune' are attributed to the anger of dead grandparents who were neglected or mistreated in their lifetime. Even mothers and grandmothers, who rarely voice a curse against their own children, are thought to evoke an unvoiced curse with deadly effect. Again, young girls within the family may not understand why they have been denied food in times of hunger, and their curse is thought to be 'especially dangerous'. ${ }^{13}$

Straight explains the potency of a curse within the family through a more general concept known as latukuny. This term refers to substances that people exude such as their breath, sweat and tears, and it may be figuratively summarised as their 'smell'. This 'smell' is associated with each individual's good or bad fortune. For a woman, it is intimately bound up with the fire in her hut, her fertility and health. She has to nurture these by acting in ways that ensure she continues to 'smell sweet', and sweeter still as she ages. Her 'smell' infuses her personal possessions, such as her neck beads, the charcoal that she uses to cleanse her calabashes, and the firestick that had kindled her first fire when she married. The charcoal and firestick are both made from the lorien tree, a term that also refers to her 'luck'. Keeping herself 'smelling sweet' is especially important during the rigid restrictions that she must observe after giving birth, and her children are similarly restricted after their initiation. Otherwise, they will acquire a 'bad smell' diminishing their health and fortune. The potency of a curse that has been pronounced against a woman is the punitive effect it has on her latukuny - her 'smell' - and hence on her lorien - her luck. The situation is similar for an elder, whose good luck lies in generating wealth. This is his sobua, a term that is also used for the herding stick that he handles daily and waves aloft in any collective blessing (Plate IV). The same term extends to his face, his sperm, and to possessions infused with his 'smell' - his latukuny. He too has a 'sweeter smell' as his family grows and becomes well established with age. ${ }^{14}$

Taken together, the 'smells' of a husband and wife mingle with their herd. Their cattle respond to the good 'smells' that infuse the husband's herding stick, and the neck beads worn by his wife when milking. This mingling of 'smell' and sharing milk is bound up with the integrity (seerr) - 'the way of life' - of the family as a unique entity, distinguishing it from other families. Beyond the family, there is a similar notion that infuses the collective integrity and uniqueness of each clan and also the separateness of the Samburu from other ethnic groups as a way of life. It is the sharing and trust within each family in particular that makes a curse between close relatives

13 Straight 2007: 19-21, 96-7, 100, 102-3, 167-8.

14 Straight 2007: 74-8, 80-1, 99. 
so potent. The mingling of their latukuny makes them more vulnerable to the anger invoked by their acts of selfishness as the violation of sharing and trust. ${ }^{15}$

The link between this shared 'smell' and a family's good fortune - their health, fertility and the growth of their herd - is reflected in a range of conventions. No-one outside the family should take an elder's herding stick or a personal possession of his wife, or this could bring harm. To steal these out of malice is a form of sorcery [my term], designed to transfer the fortune of the owner to that of the thief, at least in the short term, although the thief also risks a lingering death. To purchase these personal possessions in order to resell them is dangerous for the owners and in the long term for the trader. Thus women's mporo neck beads are increasingly attractive in the tourist market and fetch good prices, but they are also very personal possessions infused with their personal 'smell' and they should be worn at all times, especially when milking. To alienate them from the family by selling them to tourists or traders poses a threat along the chain of transaction. ${ }^{16}$

Death within the family undermines their 'good smell'. The sense of integrity associated with this sharing is shattered by the contamination - the bad 'smell' - of death. The head of the dead person is shaved, and so too is the hair of those who shared their latukuny - their 'smell'. However, there are degrees of unpropitiousness associated with death. The deaths of younger unmarried members are invariably regarded as unpropitious, and their personal possessions must be separated from the living. When moran die, they must be laid to rest far from any settlement, and their contaminated clothing and ornaments should be left with them. Married but childless adults may be laid to rest closer to their home. Those with living children closer still, and their possessions should be cleansed and shared within the family. If a son or daughter has been initiated, then the disposal of the dead parent may be yet closer to their home. Only with the death of those who have grandchildren is there any sense of a good death, and they will either be laid to rest very close to their settlement or even buried inside it, eventually 'smelling sweet' as they did when they were alive. ${ }^{17}$

In remoter areas, the dead are still laid out and left under a tree. If a hyena feeds on the corpse, then this is taken as a reassuring sign of a good 'smell' and hence a not unduly unpropitious death. Otherwise, when no hyena is tempted by the 'smell' of the corpse, there is a lurking suspicion that the body is tainted by an uncertain unpropitiousness. In the areas closer to Christian missionary influence, the dead are now buried. However in denying the hyena the possibility of a meal, burial does not resolve the possibility of an unpropitious death. ${ }^{18}$

15 Straight 2007: 78-9, 81-2, 96.

16 Straight 2007: 74, 84-91.

17 Straight 2007: 119-21, 125.

18 Straight 2007: 122-3. 
The link between people's latukuny and their ability to curse or to bless is quite explicit in this account, as are the effects of any curse on the latukuny - the good or bad fortune - of the victims. Their bodies, bodily workings, and interaction between their persons are intimately involved. So too are their feelings. Straight's account presents an anatomy of feelings ranging from anger and resentment to the restoration of friendship and an aura of sharing and trust.

\subsubsection{The Transformation of the Curse from 1960 to 2002?}

Straight's chapter on latukuny provides an especially valuable insight into Samburu thought. This notion of bodily exudences - the pervasive smell and sweat infiltrating personal possessions - is linked to the fortune of each family. The whole topic appears to have been overlooked in earlier ethnographies on the Samburu, and indeed on the Maasai for that matter. Its implications for the operation of the curse and responses to death within the family are equally valuable.

The concept of latukuny could well have relevance also for the Samburu age system. Thus, an elder's latukuny includes his sperm, and in effect he shares this sperm with his age mates, for in the normal course of hospitality, the bond between them extends to becoming the natural fathers of each other's children. Again, a woman's latukuny is intimately bound up with her domestic fire, and this links her to her husband's age-set, for the fire was first kindled by his age-set's firestick patrons. ${ }^{19}$

In my later study of the Maasai (1976-7), the Matapato provided two pieces of information that suggest a similar concept to the Samburu latukuny. The first referred to the occasion when the age mates of a dead man come to bless his widow's hut and to brush out her hearth to make it 'smell sweet'. ${ }^{20}$ The second (unpublished) was an elder's response to my question concerning a father's attitude towards a son who had been begotten by one of his age mates. He pointed out that the son would have grown up in the same home as his brothers and sisters, drinking the same milk, inhaling the same 'smell', and making his family membership indistinguishable from theirs. Clearly, I should have pursued the point.

While Straight's treatment of latukuny is illuminating, the differences between her account of the curse and my earlier account are striking. The Samburu in 1960 emphasised the relevance of the curse in maintaining respect for older people in what was essentially a gerontocratic society. By 2002 the justification for a curse had apparently shifted towards punishing selfishness and greed, with no suggestion that age or ritual authority were necessary ingredients. Thus 'anyone can curse another if

19 Straight 2007: 74-5, 78-9; Spencer 1965: 82; 1988: 189.

20 Spencer 1988: 241. 
there is a just cause'. Apart from the odd mention of the firestick patrons' curse, the emphasis is on the family where even a hungry girl's curse is dangerous. ${ }^{21}$

Jon Holtzman's independent research on Samburu food memories lends clear support to (his wife) Straight's view of the curse. He suggests that sharing food creates a bond through the proximity of the giver's latukuny, and his ability to curse the receiver builds up with the extent of the sharing. Moreover this may be reciprocated if the receiver gives his labour (and sweat) in return. As Straight puts it, the most intense sharing of latukuny and a potent curse occur between close relatives. ${ }^{22}$

From this point of view, the ability to curse has now apparently shifted from an earlier emphasis on respect for age to a respect for anyone's feelings, whatever their age, especially concerning food. This implies a switch from a society that was dominated by strong institutions in 1960 - clanship, the age system, and the patrilineal family - to one in which only the family emerges as of prime significance by 2002. Straight barely mentions clanship or clan-based ritual gatherings. The agesystem and 'firestick' relationship between alternate age-sets are briefly noted, but apart from these snippets, the age system is largely relegated to a means of indicating men's ages. There is no mention of reciprocal powers to curse within an age-set or between ritually bonded segments of the clan system. In other words, the wider social context of cursing (and blessing) seems to have lost its structure, a structure that was quintessentially Samburu in the earlier study. ${ }^{23}$

This implies a massive shift of attitudes over a period of just three age-sets - long enough for an ageing morani to grow into an ageing though still active elder. But how uniform has this transition been? During the first decade of post-colonial Kenya, when the Samburu were seriously threatened by Somali intrusions across their eastern borders, there were few pressures for change. In 1973 on a brief visit to the Ariaal near Marsabit, I came across a remote colony of families of my own adopted clan (Pardopa). The elders were able to supply me with a complete update of migrations and deaths among my earlier sample of 566 Pardopa elders, who were living up to 150 miles away, scattered over an area the size of Wales. Yet the same elders had no notion of current affairs in the neighbouring colony of a Masula clan. Clanship among the Samburu, it seemed, showed little sign of change. In 1976, a brief visit to Pardopa families living on the Leroghi Plateau revealed minor relaxations in the age system affecting marriage and initiation restrictions on moran, but no significant change. A revealing sign of stability in the Samburu age system has been the continuing age-set span of about 14

21 Spencer 1965: 300, Straight 2007: 96.

22 Holtzman 2009:73, Straight 2007: 96. Holtzman's argument can be extended to relations between age mates, for each age-set is characterised by sharing food and each other's company, and this bond is extended to the notion of an age-set curse. (Spencer 1988: 76, 189-90.)

23 Spencer 1965: 78, 88; Straight 2007: 29-32, 75, 96. At odd points in her text, Straight uses the term 'generation' as an alternative for 'age-set'. 
years from the earliest records up to the most recent initiations of 2005. The Samburu did not count the years, but pressures for new initiations would build up from all sides (Chapter 5), and this consistency in the span of age-sets suggests no apparent change in the demographic forces that govern their age system, despite the massive growth of population and other economic and socio-political changes. ${ }^{24}$

In the context of changing attitudes towards the curse, material from the Maasai is revealing. The Samburu and Maasai both claim a common origin, and Straight draws on Maasai data at intervals throughout her book. My fieldwork among the Maasai in 1976-7 revealed some striking differences from the Samburu. Clanship among the Maasai was barely significant by comparison, and without the constraint of clansmen the family seemed altogether more patriarchal. The age system and its ceremonial aspects were altogether more elaborate among the Maasai, especially in the organization of the moran as a preparation for elderhood. Elderhood was marked by an obsessive concern for solidarity between age mates, backed by physical sanctions as a means of avoiding a devastating age-set curse (Chapter 4). There is a clear contrast between the sense of belonging within each Samburu clan as against the unrelenting loyalties within each Maasai age-set. Again, while sorcerers and people with 'eyes' had been noted as marginal to Samburu society and attributed to their non-Samburu neighbours, these were very significant images that haunted the Maasai, notably over suspected sorcery. The Prophet for each of the 16 Maasai sections was a trusted father-like figure, a super-sorcerer who protected his people from the ravages of lesser sorcerers whereas the Samburu by comparison claimed to have only minor diviners with mixed reputations and very little sorcery. Yet, despite this range of differences, the Samburu in 1960 and the Maasai in 1977 were virtually identical regarding the basic principles underpinning their beliefs in the curse, although admittedly there was a more scrupulous concern to avoid an age-set curse between Maasai, and there was a greater fear of the mother's-brother's curse in Samburu. Among Maasai, it is not the mother's-brother who has a bad image, but the father's-brother. Without clan constraints, there is a general sense of rivalry within the Maasai extended family and a caricature of a guardian uncle who oversees his dead brother's family portrays him as an unscrupulous sorcerer. In other words, whatever the historical processes that could account for clear differences between the Samburu and Maasai in the course of their moving apart, beliefs in the curse appear to have been remarkably resilient over time. ${ }^{25}$

While one may question the extent of change among the Samburu during the post-colonial period, there clearly has been change, and one cannot simply disregard Straight's account of the curse. In a significant passage, she writes: '... in the case of a curse, one's eyes may be the first to alert the stomach of another person's

24 Spencer 1965: 320-1; 1973: 149; Straight 2007: 31.

25 Spencer 1988: 36, 103-7, 219-22, 225-6, 250-1; Spencer 2003: 98-123. 
wrongdoing. A common cause... is the withholding of food from a hungry person. It is a terrible infraction to eat in front of a hungry person or to withhold food from such a person when the latter knows that food is available. As I heard many times, the hungry person's eyes send a message to their stomach and a curse begins to form and be stored there. ${ }^{26}$

This slant on the curse bears a striking resemblance to the (1960) Samburu belief in the ability of their Turkana neighbours to harm through their 'eyes'. This is a theme that was elaborated by the Maasai (in 1977), who suggested that people with 'eyes' could 'see' inside other people. They could 'see' what food they had just eaten or the sex of a pregnant woman's unborn child. They might be benign and fully accepted members of the local Maasai community, but if they became hungry or jealous, their involuntary greed could bring illness and even death to vulnerable victims, especially the young. Those 'with eyes' might be men or women, and as a matter of routine (as for a blessing) they would be expected to spit in order to annul the effect of their 'eyes'. Children would be warned not to wander off into the bush in case they met someone with 'eyes', and they would hide behind their mothers' skirts when strangers appeared in the village for the same reason. Initiates would smear chalk on their faces as a protection from the jealousy of people with 'eyes'. When a stranger joined a local group of elders, he could be made welcome with the warning that he should spit if he had 'eyes'. Unlike sorcerers, there was no suggestion of malice in having 'eyes', except in risking misfortune by concealing the fact. Maasai diviners and even Prophets claimed that they had no magic that could detect or cure the danger from 'eyes'. ${ }^{27}$

There is a further possibility. The Maasai suggested that the danger of 'eyes' was not just from certain abnormal people, but also from any gathering of men or women. When those who had lost children saw initiates dressed up and parading, they might remember that their own dead son could have been among them. When they saw a pregnant woman or a young mother with her infant, they again could be reminded of their loss. At any public occasion with a crowd of onlookers, there were bound to be a considerable number who were grieving inwardly, and their collective grief could harm the vulnerable. Those who were aware of these feelings within themselves should spit. ${ }^{28}$

This touches on a world of symbols stemming from deep emotions and focusing on vulnerable forms of life. The young of any species were thought by the Maasai to be particularly vulnerable. Unkindness to a small child, harassing an initiate, or killing a pregnant animal were seen as unpropitious acts that could bring untold harm to the perpetrator. Conversely, all forms of play, including dancing among moran and their girls and also women's dancing, were thought to have a benign influence on

26 Straight 2007: 96-7.

27 Spencer 1988: 43-4

28 Spencer 1988: 44, 60. 
community life. Where Straight draws attention to mystical notions associated with hyenas, elephants, and certain species that have a rapport with particular families, she is touching on this other world with its propitious and unpropitious aspects. In this vein, it is quite feasible that withholding food between those who share latukuny is unpropitious and can bring harm without invoking a curse. The whole topic bears on a wide range of emotions that are beyond human control. ${ }^{29}$

More dramatically, Maasai women were perennially concerned with their fertility and sometimes gathered as an angry mob to punish anyone who had endangered this (Chapter 4). Their anger was thought to release dangerous forces that needed to be averted through an elders' collective blessing. The Maasai saw anger as particularly dangerous. An angry moran would want to fight. Elders learned how to direct their anger in order to inflict a curse, or better still how to avoid excessive harm by suppressing this anger and vetoing a marriage instead. Fertile women were not felt to have the same control over their emotions and this made their collective anger dangerous, bringing uncertain misfortune to the community at large. This was a grey area that bordered on the unpropitious (kotolo) that was 'hated by God'. Some might loosely refer to uncontrolled anger as a directed curse (ldeket), but others denied this because the harmful effects were more random. Straight appears to have focused on this grey area in her more generalized description of the curse among Samburu in $2002 .^{30}$

Accepting the thrust of both earlier and later interpretations of the curse raises a number of questions.

- Could the concern over mystical misfortune caused by withholding food between those who share latukuny be another grey area where the specific notion of unpropitious behaviour (kotolo) overlaps the general notion of a curse (oldeket)? Could the distinction between these notions have merged over 42 years?

- Could it be that the Samburu belief in the deliberate harm caused by a valid curse has merged over 42 years with their belief in the involuntary harm inflicted by the 'eyes' of a hungry person? ${ }^{31}$

- Do the Samburu share the Maasai notion of a broader interpretation of 'eyes' as the unpropitious effects of suppressed emotion?

- Do the Samburu distinguish forms of cursing between those who share latukuny from curses invoked by elders beyond the family?

29 Straight 2007: 14-15, 18-19, 89, 105, 122, 131-2; Spencer 1965: 126; 1988: 39-43, 61-2; cf. 1973: 61-5. 30 Spencer 1965: 64; 1988: 120-1, 202, 205-7; 2003: 36-7, 76.

31 Straight (2007: 230 n. 10) clearly anticipates the problem, noting that Samburu beliefs in the power of the curse and in the hungry 'eyes' of Turkana (and of some Samburu) are distinctly separate. Turkana infiltrated into Samburu District throughout the twentieth century, and this may have increased the concern for people with 'eyes' in the post-colonial period (Spencer 1965: 186; Spencer 1973: 117, 158-60; 2003: 214-5 n 
- Within a family, can a disgruntled and hungry junior member really curse a senior member (eg. a father or older brother) who should otherwise be respected and even feared for his power to curse?

- Do Samburu age mates share latukuny? And is the ability to curse between age mates perceived in these terms?

In 1960, Samburu elders were quite specific regarding the operation of the curse, but the nature of unpropitiousness was obscure. They were sticklers for ritual convention because generations of usage had convinced them that this was propitious and therefore any departure could be mystically dangerous. On such matters, women sometimes claimed that the elders knew, but the elders claimed that no-one - not even diviners or Maasai Prophets - could know. As they said again and again in answer to questions on the subject, in a cosmos ordained by God, 'It is only God who understands' - or God knows (Enkai nayiolo).

\subsection{God and Afterlife}

\subsubsection{Perceptions of an Unknowable God among the Samburu in $\mathbf{1 9 6 0}$}

In 1960, the Samburu believed in a benign universe under the protection of Enkai, their God. The same term (enkai) referred to rain and the sky. However, God was also in the world of nature around them as part of a grand scheme of things, inscrutable in the final resort, but generally benign nevertheless. When misfortune struck, this showed a more terrible side of God, whether it was lightning striking in anger from above or a fatal encounter in the bush. The most hopeful strategy towards appeasing God was followed by the elders in their formal meetings. These would be held beyond the earshot of any villages, which were places for women and children. The elders' discussions were punctuated by collective prayers, invoking the blessing of God at key moments during their ceremonies or after a heated debate, when the compromises on all sides were sealed in a spirit of sanctified unanimity. The concerted throb of these invocations - 'Nkai ... Nkai ...Nkai ...' - had an aura of power and authority. At such moments of climax, one is reminded of Durkheim's analysis of the sense of some supreme external Being generated by large consensual gatherings, the awareness of a collective consciousness that dwarfs the self-centred senses of any single individual a notion of God as a metaphor for the power of society at one with itself. ${ }^{32}$

The inference of all-male blessings seemed to imply a male God, even though Enkai had a feminine prefix. When I asked a Samburu elder if God might after all be female, he replied (as always), 'We don't know. It is only God who knows.' Then

32 Spencer 1965: 177-8; 2003: 78; Durkheim 1915: 218. 
he added with a chuckle, 'But it wouldn't be a woman'. Nevertheless, this male bias was matched by the notion of God as the giver of life through women. While giving birth, the mother would be surrounded by other women singing prayers that invoked God's blessing, and the new infant was felt to bring a touch of God's presence. To this extent, women were held to be uniquely close to God in the context of their fertility, and elders fully acknowledged this. ${ }^{33}$

The sanctity of birth contrasted with the unpropitiousness of death, where there was no notion of God being close or in any way involved. On laying out the corpse, the mourners would put fat in its mouth, lay a green sprig over it, and address it: 'Father (etc). Lie in peace.' There was no explicit suggestion of any afterlife, but rather an awareness that unpropitious forces could surround the occasion, notably in unusual circumstances when there could be an element of panic in disposing of the corpse. A Samburu elder once asked me about the Christian missions' belief in afterlife. 'Have they never seen a corpse?' he demanded. 'Cant they see that person is dead?' While birth was regarded as full of promise and intimately involving God, death was associated with an unpropitious sense of isolation and loss. ${ }^{34}$

Evading the question of gender, the human qualities of God seemed to focus more on age. Samburu descriptions of an omniscient and eternal Being suggested the characteristics of extreme old age. The oldest and most respected elders would lead the prayers in any assembly. Their age and experience were held to have given them great wisdom and understanding. The image of God was like this, but infinitely greater. Governing over a gerontocratic society, God was the supreme gerontocrat. ${ }^{35}$

Nowhere was the image of God more gerontocratic than in support of the elders' authority, which demanded respect for their age. Brushes with the unpropitious apart, an alternative cause of misfortune was held to be the result of some curse, and this too was a topic for speculation. In such matters, God was the ultimate arbiter. If a man who had been cursed was innocent, then he would be protected. If he was guilty, then he would be punished. The legitimacy of the curse hinged on a breach of respect towards someone who should be respected. A legitimate curse uttered in anger was an appeal to God and would provoke the wrath of God. A blessing would invoke God's benign protection. ${ }^{36}$

This general view was elaborated when Samburu would claim that while there was only one God (Enkai), God was also a realm of guardian spirits that replicated the world in which they lived. Every human, animal, age-set, clan, mountain, tree, rock,

33 Spencer 1973: 80; 2003: 67. Corresponding to the notion of God as the giver of life among women, ritual sacrifice by elders was seen as entailing a gift of life from God, rather than as a piacular offering to God. God was in the rain that rejuvenated the grass that fattened the cattle; and eating the sacrificial meat of these cattle served as a revitalising blessing (Spencer 1988: 141-2).

34 Spencer 1965: 272-3; 1973: 107-9; 2003: 67.

35 Spencer 1965: 177-8; 1988: 49; 2003: 72.

36 Spencer 1965: 186, 188; 2003: 76-7. 
or anything that was an entity in itself had its guardian spirit (enkai). The special ability of diviners to predict, of ex-Rendille to curse, or of unpropitious objects to bring harm were all due to the special relationship between the person or object and their guardian spirit. The ability of ritual specialists to interpret the baying of a hyena or the markings of a cow hinged on the unusual rapport between their own guardian spirit and the guardian spirit of the hyena or cow. The fact that non-Maa neighbours of the Samburu had different customs that brought them good or bad fortune was because they had different guardian spirits that were relative to their situation and irrelevant for the Samburu. The God that the Samburu prayed to for protection was in the final analysis the guardian spirit for all Samburu, incorporating all other guardian spirits in their area and structured in the way that their society itself was structured. A Durkheimian view of God as a projection of social and cultural unity was expressed in their terms as an unknowable world of guardian spirits who were custodians of the Samburu moral and ritual order. God was seen as an unknowable presence, and the notion of guardian spirits was regarded as an unknowable interpretation of this, for no-one could 'know'. Regardless of interpretation, however, there was absolute certainty concerning the inherent cosmic order. ${ }^{37}$

Guardian spirits were directly implicated in any blessing or curse. When an elder blessed a junior, then his guardian spirit would add his protection to that given by the guardian spirit of the junior, who would then be doubly protected from harm. If the elder cursed the junior for no good reason, then the junior's guardian spirit would still provide protection and the cursor's guardian spirit would be powerless to inflict harm. However, if the elder had good reason to curse, then the junior's guardian spirit would 'throw him (or her) away'. In this state of abandonment, the junior would become the victim of the avenging guardian spirit of the cursor. When the Samburu heard thunder, they would sometimes say that two guardian spirits were arguing over the uncertain fate of some victim. If someone was then struck by lightning, then this implied that the victim had been justifiably cursed. The critical issue in seeking a blessing after any curse was to restore good relations between cursor and cursed, but also between the cursed person and his or her guardian spirit. To be in a cursed state (ngoki) was dangerous, and to prolong this by not seeking a blessing was foolhardy,

37 Spencer 1973: 112-16; 2003: 85-7. The Maasai suggested that their expression that every person had their 'own spirit' (enkai enye) was a colloquial way of saying that some people have unusual luck. Their belief in one God did not stretch to any concept of guardian spirits beyond this. However, the domain claimed by the Prophet for each Maasai Section extended to all the people, animals and features within 'his' territory, and this was identical in scope to the domain associated with the guardian spirit for all Samburu, although the Prophet's power was limited to insight rather than omnipotence. From this point of view, the Samburu as a whole could be viewed as a peripheral Section of the Maasai. Among both Samburu and Maasai, diviners and Prophets could help in diagnosing the causes of misfortune and suggest suitable precautions and remedies, but they were held to have no clearer insight into Enkai's domain than other men. (Spencer 1973: 72 n.2, 114-5; 2003: 81, 106-7.) 
for the cursor might die and the cursed person would then be permanently without a guardian spirit and at the mercy of elemental forces. Guardian spirits, then, had castigating as well as protective aspects. ${ }^{38}$

There was a considerable overlap between the belief in personal guardian spirits and parental roles within each family, which also had both protective and castigating aspects. Up to a point, this might be seen as a division between the mother's role as the bedrock of day-to-day existence and the father's authoritarian role as undisputed head of the household. However, the father was also perceived as fulfilling both roles according to context. As an elder, he was the intermediary with the wider society, and had the experience and wisdom to ensure the family's continued survival in terms of the wellbeing of the herd and of negotiating worthy marriages for himself and his children. As head of his household, he had to be a disciplinarian with the authority to ensure that his sons learnt the skills of herding from an early age and that his daughters above all acquired a keen sense of respect to maximize their chances of a good marriage. Thus guardian spirits could be regarded as having all-male or a mix of male and female attributes. ${ }^{39}$

The belief in the unquestionable fairness of guardian spirits (or God) in deciding whether or not a curse was justified brought with it an irrational contradiction. Did this justification extend to an arbitrary and sometimes extreme form of the punishment? Was it fair that punishment for a minor show of disrespect should threaten the wellbeing and even the lives of the victim and the victim's descendants? Overriding any notion of fairness was the premise of an absolute authority underpinned by the unquestionable deference to age. This raised a further question. With a high rate of child mortality, how would Samburu children respond to the deaths of their siblings and friends? The generally benign and protective mood of their family life seemed to be undermined by this recurrent experience. Would these children wonder how a father could allow this to happen, unless he had contrived in these deaths? ${ }^{40}$

During my research among the Samburu, this was a matter of speculation. However, extending the question to the Maasai at a later date made this dilemma for children more explicit. The moderating bonds of clanship were weaker among the Maasai, leaving the family exposed to a harsher form of patriarchy. Whereas Samburu elders would assert that no man would want to curse his own child and risk the future of his family, some Maasai fathers were quite implacable on this topic. They would argue that persistently naughty children deserved severe punishment, and their early

38 Spencer 1973: 113; 1988: 49; 2003: 87-91

39 Spencer 1965: 10, 184, 217

40 Spencer 2003: 77-9. This argument was outlined in my early paper, 'The Dynamics of Samburu Religion', but I then omitted the more speculative aspect in The Samburu and Nomads: in Alliance. Only after graduating to the Maasai years later did I realise that my evidence on this was now strong enough to consider it seriously (Spencer 2003: 78-81). 
deaths would serve as a warning for their siblings to behave themselves. Other Maasai denied that they would ever curse their own children, but both sexes admitted that this could happen and that distraught mothers could threaten their children that they would ask the fathers to curse them (cf. a guardian spirit abandoning a guilty dependant). ${ }^{41}$

Samburu parents did not go that far, but - pursuing the speculation - the dilemma for children persisted. If deaths were not the will of the father, then there was still the wider community of elders. With their lives centred on the village, children were expected to avoid elders, and they gained a respect amounting to fear of the elders at large. Assemblies of these elders, debating and blessing somewhere out there in the bush, were the ultimate guarantee of protection - and the threat of punishment. Viewed from a distance by dependants, these assemblies generated an awe-inspiring spectre of power, and children were warned to keep their distance or they might be cursed.

The assemblies were the intermediaries with God, and it is tempting to regard elders' perception of God as a projection of their childhood experiences as onlookers. Like the assemblies, God was both protective and terrible, infinitely wise and knowing, overawing and punitive beyond human understanding. Confronted with tragedy and the destructive power of nature, the elders had a similar sense of awe of an omnipotent God as children might have of the elders' assemblies, whose protectiveness could never be entirely taken for granted. In the scale of Samburu mystique, elders were revered for their wisdom. They acquired this wisdom from experience and associating with other elders at their assemblies. The oldest elders were at the peak of a pyramid of human knowledge and understanding. However, God was infinitely wiser and more powerful than any elders, with qualities that echoed those associated with age and elderhood, but infinitely more so. In Samburu terms, a Durkheimian view of God as a projection of a sense of the power of society focuses on the sanctity and power of the elders' assembly. God was inscrutable, but the perception of God had characteristics that could be traced to their earlier family life and the ultimate authority of the remote and awe-inspiring collectivity of elders. ${ }^{42}$

This suggests that the most elementary form of Samburu religious life arose in childhood within the family, which oddly may also be said of the alternative view that we now consider.

41 Spencer 2003: 80

42 Spencer 2003: 80-1 


\subsubsection{Samburu Perceptions of God and Afterlife in $\mathbf{2 0 0 2}$}

In Miracles and Extraordinary Experience in Northern Kenya, Bilinda Straight shifts the focus of Samburu religion from their beliefs in an unknowable world of guardian spirits, to a more direct and visible experience of God. ${ }^{43}$

A striking feature of her account concerns a confusion between empathy and objectivity. Samburu metaphysical beliefs are cited as if they are unquestionable physical facts rather than essential clues that illuminate the manner of Samburu thought and cosmology. In this vein, reported 'miracles of resurrection' are miracles; the author allows herself to speculate on the intentions of the Samburu God, Enkai; and she is amused rather than alerted when a Samburu neighbour expresses astonishment at a claim of the resurrection of the dead. ${ }^{44}$ However Straight's own penchant are the flipside of her hard-earned empathy, and here I do not propose to treat these apparent contradictions as relevant for an assessment of her contribution towards an understanding of Samburu religion.

Straight's account suggests that by 2002 the Samburu view of death has shifted towards an array of notions of afterlife and a more uncertain boundary between the living and the dead. In order to maintain a propitious relationship with their dead parents, the living now place offerings of food and tobacco on their final resting place. It is held that if these ancestors feel they have been neglected, they may remind the living by visiting them in the guise of some animal or by affecting the behaviour of their herds. A more serious negligence can even result in the deaths of a succession of offspring. In one case where an elder repeatedly neglected his living mother, she is said to have haunted him in his dreams after her death, refusing to be placated, and hounding him to his own death. The possessions and all traces of those that have died childless are separated from the living, and their ghosts remain dissatisfied for there is no-one to feed them. This makes them powerless to inflict harm, but they can unsettle the living as they wander back and forth, appearing as misty white shapes that call to the living and visit the very sick to accompany them to their death. More benignly, it is thought that the propitious ghosts of older people may visit their friends, enticing them to die in peace and without fear. ${ }^{45}$

43. A further problem in Straight's volume concerns the esoteric nature of philosophical explanation. She offers her own critique on a range of writers concerned with the limits of phenomenological experience. This is not to denigrate the discourse that she is tuning into, but it is to note that this kind of theory sits awkwardly beside ethnographic evidence concerning such peoples as the Samburu. Extended tracts of the text and the whole of the concluding chapter make difficult reading for those who are unfamiliar with the writings that she cites, and the fact that she does not provide the relevant pages in her references makes her philosophical analysis effectively beyond the reach of the uninitiated.

44 Straight 2007: 63, 66, 129.

45 Straight 2007: 153, 155-6, 161-9, 173-4 
Straight points out that most Samburu do not return from the dead, but she has talked to 'dozens' of others who claimed first or second-hand knowledge of corpses that had been laid out in the bush and then found to be alive. The earliest reported case occurred when the Lkileku age-set were moran (1922-36). This concerned a dead girl who had been left for hyenas to devour, but was then found by her morani brother to be sitting up and blinking her eyes. In a second case, it was a dead elder's cattle that had blown away the mortuary leaves and nudged him back to existence, revealing him completely recovered from his illness. In a third, a dead man had been laid out in the bush for four days while his dog kept the hyenas at bay, and then he recovered. In a fourth, a sick morani was so ill that others assumed he had died, but his brother refused to leave him and he slowly recovered. During his illness, this morani had hallucinations that convinced him he had died. In a fifth case, a mother refused to believe an Italian doctor's repeated pronouncement that her son was dead, and eventually he recovered. In a sixth, a dead man returned from the bush to his mother's home carrying his mortuary hide, and this experience has been shared by children who returned home dragging their burial shrouds with them. ${ }^{46}$

None of these examples suggest that God (Enkai) was involved in punishments by neglected ghosts or in the revival/resurrection of those who were assumed to have died. Although in odd passages, Straight does suggest that the 'space of Enkai [is] also the space of death', and Enkai is closer to the deaths of the young and very old. Children are 'the most frequent visitors to Enkai and the most common to resurrect', and grandparents may be buried benignly within their own settlement because they are closer to Enkai. These suggestions are not elaborated, and more remarkable is Enkai's perceived involvement in Samburu affairs in other ways. ${ }^{47}$

According to these beliefs, Enkai may appear as a rain-cloud or a large snake in a cave, or more strikingly in the guise of a wealthy family with warnings that echo moral predicaments facing the Samburu. In the earliest remembered appearances, Enkai warned against selfishness, and the arrogance and disrespect of young people. Girls especially were criticised for having adulterous affairs with elders and for being too proud of their appearance to give milk to hungry kin and neighbours. Affluent young people who bathed in milk were criticised for their excessive display of wealth and pride. It is said that these violations of public morality led Enkai to inflict widespread destruction on the Samburu in the 1870s, when the Tarigirik age-set were moran. ${ }^{48}$

In the twentieth century, Enkai is said to have punished individual families, inflicting fire and flood on the home of a woman who had refused people water for their animals. The family of another woman was destroyed by thunder and rain because she had had an incestuous affair. Indeed, stories of Enkai killing individuals

46 Straight 2007: 5, 13, 129-131, 150-1, 173

47 Straight 2007: 121, 170, 176

48 Straight 2007: 47-8, 54, 59-62 
for selfishness and especially 'grievous acts of adultery as in incest are too many to recount'. More recently Enkai is held to have been concerned with shifts in Samburu behaviour that reflect the transition in their lifestyle, such as the use of plastic bottles instead of traditional calabashes for milking, and wearing modern forms of dress in preference to traditional adornments, notably women's valuable mporo necklace beads which have been sold to tourists. ${ }^{49}$

These examples give the image of God (Enkai) as a punitive guardian, overseeing Samburu traditions and traditional expectations. However, Straight's most graphic illustrations concern visits to the home of Enkai by the living. She notes that she has heard 'numerous accounts' of children who have wonderful stories of visits to Enkai's large and prosperous home, and such visits are 'regular, if unusual occurrences'. She interviewed three of these 'visitors', and provides brief second-hand accounts of four more. An eighth semi-mythical account dates back to the nineteenth century. Of these eight visitors, five were girls, two were moran, and one was a mature woman who had been close to death at the time of her visit. ${ }^{50}$

Their accounts are as follows.

1. Remeta's widowed mother was an alcoholic who lived in 'the most untidy disorganised house' that Straight had ever seen. At the age of about six, Remeta disappeared for a disputed length of time. She was visited by an Enkai girl, and then by an Enkai woman, and then by an Enkai morani, who all had light skins and wore white cloths. The morani led her to a sacred wild-fig tree and she found herself in Enkai's settlement, which was very large with modern-built houses, but traditional Samburu furnishings inside. Her Enkai hosts gave her milk to drink and messages to take home with her. The Enkai girl told Remeta that she wanted Samburu moran and women to stop wearing fashionable orange cloths as these competed with the lightning she flashed when she wanted to make rain. The Enkai morani showed her a spotted stone representing Samburu misdeeds for which they are punished by wars, diseases, and other disasters. He wanted children to stop drinking tea, boys to revert to their traditional top-tuft hairstyle, and women to stop using calabashes made of plastic for milking. The Enkai woman wanted Remeta's mother to stop drinking liquor. The Enkai husband was sitting nearby, but only greeted her. When Remeta returned to her own home, her guardian uncle soon told her to stop talking about visiting Enkai's home. There is no suggestion that she made further visits, but the messages that she brought

49 Straight 2007: 48, 60-63. At various points in her narrative, Straight does not clarify the distinction between 'incest' and more serious acts of 'adultery'.

50 Straight 2007: 38-41, 54-8, 61-2, 170-2 
back appear to have had some impact, except over her mother's drinking habit. Straight refers to her as a 'child prophet'. ${ }^{51}$

2. Ngoto Malapen (Malapen's mother) is described as a 'famous Samburu prophetess', who crossed into Enkai's home throughout her life. Her gifts for prophecy and healing started when she was still a young girl, and had a vision of Enkai as two women. They found her when they were looking for someone who would understand their language and take their messages back home to Samburu. While Ngoto Malapen normally saw Enkai as a woman who brought rain and gave birth to all living things, Enkai could also appear as a morani when the message was bad and carried an implicit warning. No details are given of Enkai's messages or of her visits to Enkai's home, except that it was a beautiful place where she was invariably fed. Sometimes Enkai would visit her, and was angry with her on one occasion because she had begun to go to church and was afraid to prophesy. She developed blisters which went away when she stopped going to church. ${ }^{52}$

3. When Nompoi was expected to die, she ventured into Enkai's beautiful home and could hear all that was said as people chewed a stimulant (khat) and asked for liquor. She then went outside the home and found cattle with giant udders. She tried to run after them but was turned back by the voices of dead people who warned her that these cattle were not hers. She had regained her life. In this series of accounts, Nompoi was the only 'visitor' who moved both between the living and the dead and between Enkai's home and her own. ${ }^{53}$

4. Turaso was a little girl when the Lmarinkon age-set were moran (around 1890). She disappeared for a few days and was found in a cave claiming that she had wandered into Enkai's home. An Enkai woman gave her honey to eat, while two other Enkai women argued whether they should keep her to punish her mother for taking away a wooden post from the house of a dead woman, but they relented because this had been unintentional. Turaso was then given an (unspecified) message to take home. Her father offered a sacrifice to Enkai and moved away from the area. Turaso begged him to move again as instructed, but he refused. As a result, her father then died, and Turaso was so furious that she refused to speak to Enkai for a very long time and stopped prophesying. ${ }^{54}$

5. When the Mekuri age-set were moran (around 1940), a group of children followed a goat into a cave, a fierce wind from the cave blew them out and a girl cracked

51 Interview, Straight 2007: pp. 37-41, 56-8, 62

52 Interview, Straight 2007: 56, 171-2

53 Interview, Straight 2007: 172.

54 Straight 2007: 55, 170-1 
her skull open. Enkai visited her and instructed how her father should dress the gaping wound. She survived..$^{55}$

6. A little girl went missing for a few days. She said that she had been taken by an Enkai woman to her home. The woman was nicely dressed in the leather garments worn by brides, and the herds were healthy and fat. The Enkai woman gave the girl a lot of milk and meat to eat, and a clean cowhide to sleep on. ${ }^{56}$

7. Lolsuri was a morani of Kiroro age-set and he was taken to Enkai's settlement during a disastrous drought in the mid 1980s to early 1990s. There, he was nourished by the Enkai family until he was full and then given several warnings to take back to the Samburu. Child-bearing women and children should pray to Enkai, because there was a general lapse in standards. People were cursing children, women, and even elders too readily. They were selfishly living alone with too little pity for one another or sharing food. These were the reasons for the drought that Enkai had inflicted, killing off their herds. ${ }^{57}$

8. Another morani of Kiroro age-set visited Enkai's settlement and noted that the Enkai family were wearing fully traditional clothing and beads. One of the Enkai family asked him if people dressed like this in his place, and when he answered that they didn't, he was told that they should. ${ }^{58}$

A typical feature of these accounts is that the image of Enkai is reduced from a cosmic presence to human proportions, with messages for the visitors to bring back over moral issues that range from abusive behaviour to the globalisation of Samburu lifestyles. The questions that these illustrations raise are not just the state of mind of those involved at the time of their visit, or indeed the state of mind of those who claim to have been resurrected. The more far-reaching questions concerns the gap between the two accounts, spanning the post-colonial years 1960-2002. How might one explain the development of new assumptions concerning afterlife? More dramatically, how is it that belief in an unknowable God in 1960 (embedded in the title of my volume Time, Space, and the Unknown) could be transfigured into a belief in a larger-than-life deity who has become so knowable in so many ways by 2002 (implicit in the title of Staight's Miracles and Extraordinary Experience in Northern Kenya)?

55 Straight 2007: 55

56 Straight 2007: 54

57 Straight 2007: 55-6, 61-2. The Enkai family included a husband, wives, children, moran and livestock, but there is no indication which of these gave the warnings to the visitor. The Samburu term 'children' includes all women, and hence Straight's reference to adults appears to refer to elders.

58 Straight 2007: 55-6, 62. Here too, the Enkai family included a husband, wives, children, moran and livestock, but there is no indication which of these gave the warnings to the visitor. 


\subsection{Conclusion: The Extraordinary Transformation of Samburu Beliefs}

At first sight, differences between the earlier and later models of Samburu religion are so stark as to beggar comparison. In 1960, Samburu elders totally discounted any suggestion of afterlife. They regarded Anglican and Catholic missions as a general asset for the Samburu, and the premise that they had access to God's domain seemed supported by the clear superiority of Western medicine and technology. At the same time, the missions' creed concerning the survival of life after death was abruptly dismissed as just lies.

Yet the Samburu fear of the unpropitiousness surrounding death in 1960 is not altogether incompatible with Bilinda Straight's description of their belief in ghosts in 2002. The need to separate the living from the dead in order to avoid the mystical contagion of death was similarly expressed, shaving off their contaminated hair, disposing of personal possessions, and addressing the corpse to lie in peace. Particularly telling in 1960 was the practice of laying to rest any dead man who had breached the rules of exogamy. When his sons left the corpse, instead of placing a green sprig over it and saying 'Father, lie in peace', they were said to snap dry twigs over the corpse, shout 'Mother's-brother, do not harm us', and then run away. This was not regarded as a belief in afterlife, but a bemusing custom in a rare and quite unpropitious circumstance. Nevertheless, it suggests a practice on the border between belief in afterlife and disbelief, leaving room for a shift towards belief over the next 42 years. ${ }^{59}$

Straight presents the notion of corpses who return to life as a further blurring of the border between the living and the dead: ghosts are the dead who visit the living, whereas resurrection concerns the miraculous event of the living who visit the dead - and return. She notes this as a recurring experience, and her earliest example appears to predate the arrival of missions in the area in 1934. However, the influence of missionary teaching seems very likely, and she admits that as the Samburu are increasingly exposed to Christianity, they have become generally familiar with the story of Jesus's resurrection, and they accept this as a fact. That this is a recent conversion is evident from those who continue to find the issue of resurrection 'disturbing', 'unheard of', and express 'utter astonishment'. ${ }^{60}$

The fact that the Christian message has gained a foothold may be linked to a significant transition in the disposal of the dead. Around 1960, a Consulata (Roman Catholic) missionary confided to me that there was only one aspect of Samburu society that he would like to change: they should bury their dead instead of laying them in the bush to be mauled and eaten by scavengers, such as hyenas. Burial is now

59 Spencer 1965: 149; 1973: 109, 120.

60 Straight 2007: 45, 129-31, 133, 
the norm in the Samburu highlands and the more accessible parts of the lowlands, due to increasing exposure to Christianity. None of the six instances of resurrection that Straight outlines involved burial, and it is tempting to suggest that these reports spread in a climate of rumour as the practice of burial became established, spawning new ideas. Straight gives no indication how far the belief in resurrection extends to areas less affected by mission teaching where the dead are still laid to rest rather than buried. She discusses instead the agonizing dilemma of those who now bury their dead while still uncertain whether this might stifle the chances of resurrection. Evidently, the nature of Samburu beliefs in 'resurrection' - however one might explain the individual examples - suggests a physical rather than spiritual interpretation of the Christian message. ${ }^{61}$

The only substantial concession that Straight makes to the influence of Christian missions is the growing assumption among educated Samburu that Enkai is male, rather than variable in appearance. Yet she also notes parallels with the Old Testament God, who similarly visited the sins of the fathers upon their children through the generations; and she notes that like the Samburu, the Israelites too were pastoralists who observed numerous taboos and made sacrificial offerings to God. The examples that she gives of Enkai inflicting disasters on the Samburu in the 1870-90s because of the wickedness of a young minority is reminiscent of an angry and punitive Old Testament God with the attributes and authority of a supreme male gerontocrat. ${ }^{62}$

The previous chapter cited W. Robertson Smith's comments on 'antique' religions, noting that Semitic religion consisted of ritual institutions and practices rather than creeds. Precedents had to be followed accurately, whereas explanations were irrelevant and could be vague or inconsistent, but this did not matter. This attitude towards religion applied very clearly to the Samburu in 1960. In as much as they did have a creed, it was that God (Enkai) would punish any departure from standard ritual practice. No further explanation was necessary. ${ }^{63}$

In contrast to this, Straight's presentation of Samburu beliefs in 2002 suggests an irregular discourse between a random selection of humans - notably girls - and a tangible and articulate Enkai. Apart from the stern warnings conveyed by Lolsuri (case (7)), the messages that the others are reported to have brought back were essentially concerned with ritual correctness at a rather trivial level. This does not just imply new beliefs, but a radically new approach from a practical religion that bonded with daily life in 1960 to an embryonic eschatology that floats above the dynamics of

61 Straight 2007: 122-3, 148-9

62 Straight 2007: 41, 45-6, 48, 60-1, 106, 159. In a similar vein, the most remarkable early work on the Maasai argued that they might be a lost tribe of Israel (Merker 1904: 260-339). For an alternative interpretation of Samburu sacrifice as a gift from rather than to Enkai, see Spencer 2003: 74, and n. 33, above.

63 Smith 1907: 16, 17, 20; Spencer 1965: 307; 1973: 112; 2003: 110. 
daily existence. It suggests a transition that is no less profound than a switch from the Pentateuch to a surrealist slice of the New Testament. Following Robertson Smith, it may be regarded as just an irrelevant creed that has no bearing on ritual precedent in the hands of the elders. Or is there a genuine movement towards a new religion with its own 'prophets', as Straight implies, corresponding to Africanized forms of Christianity elsewhere? In other words, have the 'messages' brought back by 'visitors' to Enkai's home had a tangible impact on Samburu behaviour?

There is an alternative ahistorical explanation that may account for the apparent transformation of religious notions between the 1960 and 2002 models, and this concerns gender bias. My understanding of the Samburu as a gerontocratic society in 1960 focused on the interplay between dominant elders and fledgling moran, whose subversive activities presented an alternative reality that challenged the elders' regime without undermining it. By my age, I was identified with the Kimaniki age-set who were moran on the brink of elderhood, and in effect I walked along a political tightrope between the two domains. Similarly, women were subjected to the domination of their fathers, their husbands, and the elders at large, and this produced a further source of subversion, notably through their adulteries with moran. But the widespread suspicions among elders and a conspiracy of shared secrets among wives created a further tightrope that was too sensitive to tread. I was firmly entrenched within the male domain, negotiating just one tightrope. While I knew the wives and mothers of some of my male informants quite well, I accepted their assurances on matters of religious belief that I should ask the elders, who understood these matters. With such responses and biased towards a male view, it did not occur to me that these women might share a set of beliefs into an alternative Samburu religion. ${ }^{64}$

Late in my fieldwork, I overlooked an episode that could have corrected my bias. This occurred when I was visited in the low country by a very congenial Anglican missionary. After we had parted, I saw him conducting a service outside a nearby settlement, standing in a circle with perhaps ten Samburu women. The local elders were bemused and did not join them. At the same time, they did not disapprove of their wives' involvement, pointing out that women have a special relationship to God through their fertility, and only good could come of this kind of involvement. Years later in 2001, Fr Virgilio Pante was ordained as the Catholic Bishop of Maralal. A photograph of his installation shows the bishop also surrounded by Samburu women, with children in the foreground and perhaps one elder (far right, Plate V). I was told that the beads on his vestment had been sewn on by these women. Christianity clearly has made inroads into the women's domain. ${ }^{65}$

64 Spencer 1965: 211-54.

65 I am grateful to Fr Pante for permission to reproduce this photograph. 


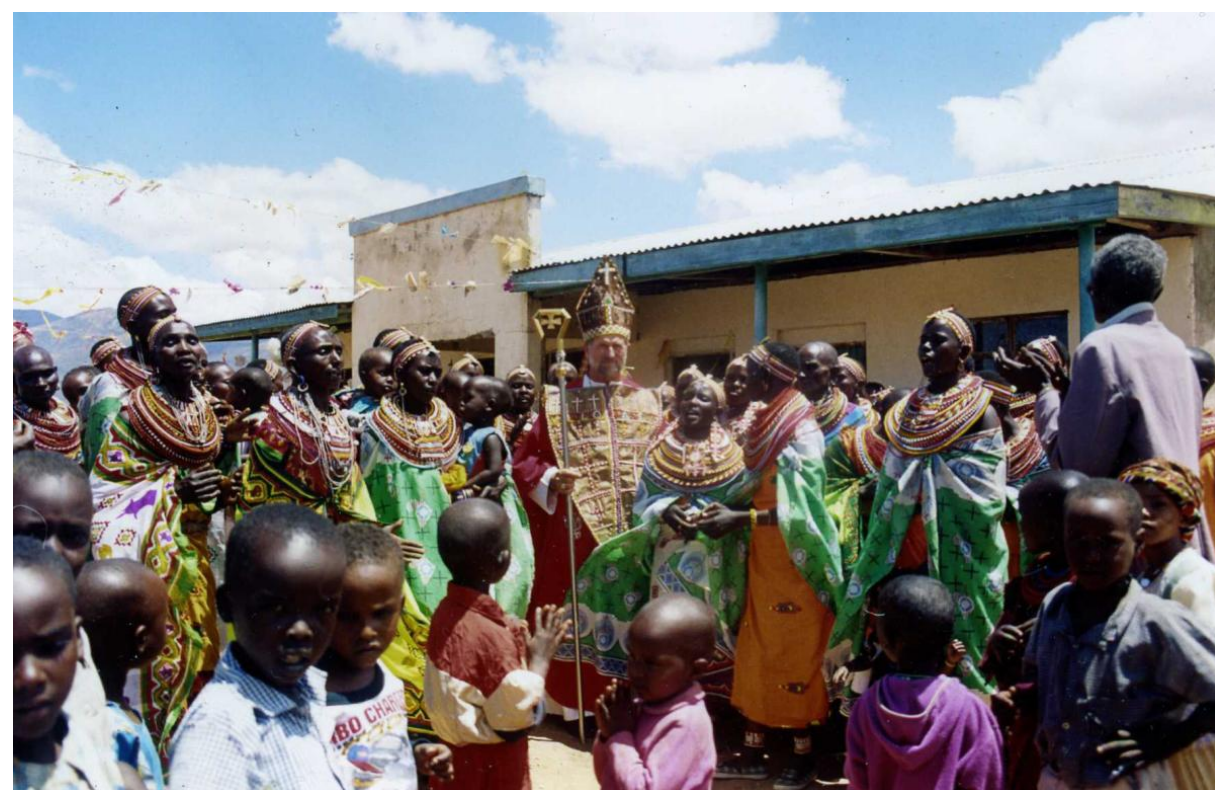

Plate V: The installation of the Catholic Bishop of Maralal in October 2001

This leads me to suggest that Staight's women informants have played a major role in shaping her understanding of Samburu religion and that corresponding to the male bias in my earlier account, there is good evidence to suggest an opposite bias in Straight's later account.

In Straight's eight cases of those who have visited Enkai's home, one is a mature woman, two are moran, and five are girls. One of these girls continued to visit Enkai throughout her life. While Straight suggests that children visit Enkai's home and are the most frequent 'visitors', none of these children in her sample are boys. And none of the 'visitors' are established elders. ${ }^{66}$

In the same sample of cases, Enkai as an elder is only mentioned once, when he merely greeted Remeta (case (1)), whereas the other manifestations of Enkai who fed Remeta and gave her messages to take home included an Enkai girl, an Enkai morani, and an Enkai woman. In Ngoto Malapen's repeated visits (case (2)), Enkai appeared as one or two Enkai women or an Enkai morani. In Turaso's visit (case (4)) there were three Enkai women. The girl in case (6) was taken by an Enkai woman to her home. The two moran who visited Enkai's home (cases (7) and (8)) interacted with the Enkai family, but there is no indication of the status of whoever fed them or gave messages.

66 Straight 2007: 7, 37, 54-5, 176. However, Straight does indicate that 'even young elders' sometimes 'visit' Enkai (but apparently not more mature elders). 
Again boys appear to be absent in this sample, while the token elder plays a low key role with no messages to offer.

Moran, on the other hand, appear as both 'visitors' and manifestations of Enkai in this sample. That Straight's bias is against elders rather than against all males is again suggested in citing the myth of an appearance of Enkai as a man at a wedding clothed in rags. Others laughed at him and he turned them into stone statues. Straight supposes that he was 'probably' a morani, but the image seems to suggest a ragged elder rather than any finely attired morani. In this gerontocratic society, elders are opposed to moran who are their precocious sexual rivals and they are opposed to women who are their wayward inferiors. Moran and women are natural allies, and women of all ages dote on the notion of moranhood and the clean image of moran. The inclusion of moran in these visits to Enkai's home is no anomaly. ${ }^{67}$

In Straight's account, the absence of elders as 'visitors' to Enkai's home and their low-key presence as manifestations of Enkai contrasts with any gerontocratic image. Whereas the Enkai who punishes Samburu from time to time in the same account appears to have many characteristics of a powerful elder. More powerfully still, as in the 1960 model, Enkai has the attributes of a formal assembly of wise and ageing elders in prayer, who are avoided in awe by women, moran, and children. In contrast to this alternative image, the experience of Strait's 'visitors' - women, moran, and girls - was of a more domesticated Enkai, and even Remeta aged six overcame her fear (case (1)). ${ }^{68}$

The preponderance of girls over boys in these case studies may also be examined in the context of their differences in status. Straight notes the extent to which girls are peripheral to the family because they will leave on marriage. Their education lags behind that of boys and they do not understand why they should be denied food in times of hunger, whereas hungry boys are directly involved in the future of the family and jokingly pray for more livestock. In 1960, this disparity was expressed differently. In order to make a good marriage girls had to learn respect and were made to avoid elders from an early age, leaving their mother's hut before a visiting elder could enter. The virtual absence of elders in 'visits' to Enkai's home seems to bear on the sensitive avoidance between elders and girls in particular and the elders' ambivalent relationship with the domestic domain more generally. ${ }^{69}$

Could it be significant that Straight takes two folk-tales told to children by older women as authentic insights into Enkai's realm, blurring the distinction between children's stories and religious beliefs? One of these folk-tales concerns a Samburu 'Genesis' myth suggesting that originally the Samburu could move freely up and down a leather strap that Enkai had dropped down to Earth, and they were given

67 Straight 2007: 47-8, Spencer 1965: 102.

68 Spencer 2003: 77-8.

69 Straight 2007: 28, 97; Spencer 1965: 212-5. 
any gifts they asked for. Then the strap was severed by a Dorobo (hunter/gatherer), separating Enkai from humans and giving rise to death. The second folk-tale concerns a Maasai moran who is separated from his age-mates and tricks his way to Enkai's village, which recedes as he approaches, and then an Enkai woman feeds him and gives him a large herd of cattle. ${ }^{70}$

This is not to suggest that what were Samburu or Maasai children's stories have now become mainstream religion, but it is as if they come from the same stable, providing related scenarios. There is a similar element of bizarre fantasy in Samburu folk-tales as in Straight's case examples of 'visits', characterized by the title of her work, and a similar range of players.

There does not appear to be any systematic collection of Samburu folk-tales. But a number of authors have published a useful selection for the Maasai which seems to overlap the few available for the Samburu. An analysis of 39 of these stories in Table 7.1 reveals different profiles in the roles played by girls and boys, and again the marginalization of elders. ${ }^{71}$

Table 7.1: Recurrent themes in thirty-nine Maasai folk-tales.

\begin{tabular}{lllllll}
\hline \multirow{2}{*}{ Themes: } & \multicolumn{7}{c}{ Principal characters: } \\
& Small animals & Boys & Moran & Elders & Women & Girls \\
\hline Outwit powerful adversaries & 9 & 6 & 3 & 1 & 2 & 2 \\
Kill monsters & 1 & 4 & 5 & - & - & - \\
Kill wicked (step-) parents & - & 3 & - & - & - & - \\
Kill enemies of the Maasai & - & - & 3 & - & - & - \\
Face ridicule & 1 & - & - & 4 & 1 & - \\
Face punishment & 1 & - & 3 & 3 & 5 & 1 \\
\hline
\end{tabular}

Like children in this table, small animals are pitted against more powerful adversaries. Boys especially have a high profile, consistent with their aspirations for moranhood, whereas the high profile of girls in Straight's examples may be seen as offering the possibility of an alternative future. The themes in her case examples are of course quite different, although some of the Maasai folk-tales that she does not consider do concern interaction with Enkai and the resurrection of monsters and their victims. These are not wholly unfamiliar topics in the Maa-speaking region.

70 Straight 2007: 50-1, 55, 153; Kipury 1983: 10, 30-1, 107-10.

71 Spencer 2003: 52. 
The point to stress is the striking contrast between the 1960 male-oriented gerontocratic model on the one hand, when compared with the 2002 model and folk-tales on the other. This suggests a number of issues of belief that need to be clarified. Such an enquiry would cover the following questions.

- To what extent does the tightly structured self-presentation by the Samburu of themselves in 1960 survive and among whom?

- $\quad$ To what extent does the notion of Enkai as the supreme super-gerontocrat in 1960 survive and among whom?

- What is the extent and nature of Christian conversion in the area?

- To what extent has the post-colonial situation shifted the balance of domestic power between elders, women and moran (and even children)?

- To what extent do 2002 beliefs and evident disbeliefs in afterlife, resurrection, and 'visits' to Enkai's home vary?

- To what extent have Samburu responded in their behaviour to 'messages' brought back by 'visitors' to Enkai's home?

- Is there an overlap between current Samburu folk-tales and accounts of resurrection and of 'visits' to Enkai's home?

- To what extent do answers to these questions differ between men and women of different ages, and educational and religious backgrounds?

- To what extent do answers to these questions differ between different areas of Samburu, ranging from the Leroghi highlands where mission influence is greatest, to adjacent lowland areas, to the less accessible parts of the lowlands where the Samburu still do not bury their dead?

Straight indicates that she has 'talked to dozens of people claiming first- or second-hand knowledge' of resurrection among the Samburu, and that visits to Enkai's home are 'regular, if unusual, occurrences'. She has heard 'numerous accounts' of children making such visits. ${ }^{72}$ The claims of extraordinary experiences are themselves extraordinary, and one needs to see them backed up with more detail and a clearer insight into changes in religious belief among men and among women since 1960. Only a balanced resolution of this problem would bring the two models into perspective and this could clarify how far Samburu religion, like their society, is diversifying at a deep-seated level. Neither study considers the dynamics of change in fundamental belief. Perhaps further shifts in the spectrum of religion may reflect change in the years to come.

The notion of an alternative religious experience among Samburu women, facilitated by their changing relationship with elders under modern conditions, raises the question of whether parallel trends have occurred among other Maa-speaking peoples. Are

72 Straight 2007: 22, 54-5, 129. 
Straight's findings unique to the Samburu or should they be viewed as part of a regional phenomenon? Certainly, regional cults involving women's concern with their fertility have been reported elsewhere, often fanned by exotic healers and imported beliefs in spirit possession. Among the Kisonko Maasai, for instance, Arvi Hurskainen (2004) has traced epidemics of spirit possession since the 1960s. These emanated from the wider non-Maa region, sharing a history of anxiety over women's fertility, with singing and dancing playing a role in the cure (cf. Rigby 1969). In Dorothy Hodgson's (2005) account of a women's religious movement among the Kisonko Maasai in the 1990s, she traces the influence of Catholic mission activities. These missions sought to integrate Christianity with Maasai culture, focussing on the education of boys, but with little success. Kisonko elders too were sceptical and held to their traditional ideologies. On the other hand, uneducated women filled the churches' congregations and displayed their spirituality as enthusiastic converts in a cult that expressed a Christian form of spirit possession and offset their subordination in domestic and local affairs, alienating the elders still further. While Hodgson's account does not suggest any marked concern over decreased fertility among the women, the polarization of religious beliefs and a striking degree of women's religious autonomy does reveal a clear shift in gender relations.

This provides us with multiple strands to the argument. Chapter 4 noted the link between the periodic frenzy of Maasai women's dancing and their obsessive concern with infertility, reflecting their depressed position. This appeared to echo a similar concern among Samburu women in 1960 and has a clear parallel with epidemics of spirit possession among Kisonko Maasai women reported by Hurkainen. In Hodgson's analysis of more recent spirit possession in this area, there is no suggestion of an overriding concern with infertility or of invading spirits, but there does appear to be an increasing confidence, expressed through their behaviour as a congregation, inspired by missionary activity. In Straight's analysis, there is again no systematic concern with women's infertility nor cults involving dancing, but also no suggestion that her evidence of Samburu beliefs in afterlife or in a tangible God have spread through Samburu interaction with missions. Indeed, Straight denies direct missionary influence in these beliefs, taking her analysis out of its historical context, and endowing it with a timeless aura. As against this, I would argue that there are too many biblical parallels - noted by Straight herself at various points - for this to be coincidence. The missionary message of 'miracles' and 'extraordinary experience' does appear to that have been elaborated in highly original ways by the Samburu. One might also note Straight's portrayal of God as a holy family on earth with an elusive father and surrounded by farm animals has a familiar Christian ring, however garbled. Again, I would surmise that Straight's evidence of the almost total marginalization of elders in her examples is telling, and it suggests that Samburu women provided the main thrust in this complex of new religious beliefs. It bears a clear resemblance to the profile of Maasai women's stories told to children, compiled in Table 7.1. Essentially, this is surely a women's domain influenced by mission activities that parallels and yet clearly diverges from a similar trend among the Kisonko Maasai. 